\title{
PROXIMAL FEMORAL NAILING VERSUS DYNAMIC HIP SCREW IN MANAGEMENT OF STABLE INTERTROCHANTERIC FEMUR FRACTURES: A COMPARISON OF CLINICAL AND RADIOLOGICAL OUTCOMES
}

\author{
STABIL INTERTROKANTERIK FEMUR KIRIKLARININ TEDAVISINDE PROKSIMAL \\ FEMORAL ÇIVI ILE DINAMIK KALÇA VIDASI: KLINIK VE RADYOLOJIK SONUÇLARIN \\ KARŞILAŞTIRILMASI
}

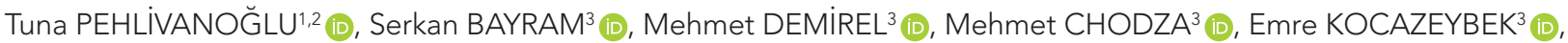
Ahmet SALDUZ ${ }^{3}$ (D), Turgut AKGÜL ${ }^{3}$ (D), Önder YAZICIOĞLU ${ }^{3}$ (DD

\author{
'Emsey Hospital, Department of Orthopaedics and Traumatology, Istanbul, Turkey \\ ${ }^{2}$ Yeni Yüzyıl University, Faculty of Health Sciences, Istanbul, Turkey \\ ${ }^{3}$ Istanbul University, Istanbul Faculty of Medicine, Department of Orthopaedics and Traumatology, Istanbul, Turkey
}

ORCID IDs of the authors: T.P. 0000-0001-8886-7538; S.B. 0000-0001-7651-1200; M.D. 0000-0003-1131-7719; M.C. 0000-0002-6996-6597; E.K. 0000-0001-7029-5076; A.S. 0000-0001-9448-6416; T.A. 0000-0002-0704-3797; Ö.Y. 0000-0002-9292-3480

Cite this article as: Pehlivanoglu T, Bayram S, Demirel M, Chodza M, Kocazeybek E, Salduz A, et al. Proximal femoral nailing versus dynamic hip screw in management of stable intertrochanteric femur fractures: a comparison of clinical and radiological outcomes. $J$ Ist Faculty Med 2021;84(4):514-20. doi: 10.26650/IUITFD.2021.964078

\section{ABSTRACT}

Objective: The aim of this study was to compare the cost-effectivity, clinical and radiological outcomes of the proximal femoral nail (PFN) and Dynamic hip screw (DHS) in the management of stable intertrochanteric femur fractures (SIFFs).

Material and Methods: Patients who underwent surgical treatment for a SIFF in our department were retrospectively identified and then divided into two groups according to the treatment modality: Group 1, 57 patients (36 female, 21 male; mean age $=74.5 \pm 9.9$ years) treated with PFN and Group 2, 65 patients (34 female, 31 male; $72 \pm 10.2$ years) treated with DHS. Primary outcome measures were: estimated blood loss (EBL), total operating time (TOT), duration of hospital stay (DHS), rate of postoperative complication, rate of mortality, and treatment cost. Radiographic assessment included anteroposterior/lateral tip-apex distance (TAD) and amount of limb length discrepancy (LLD).

Results: No significant differences were observed in demographic characteristics between the two treatment groups ( $p>0.05)$. The mean follow-up was $44.2 \pm 31$ months in group 1 and $53.7 \pm 38$ months in group $2(p=0.077)$. The mean TOT and

\section{ÖZET}

Amaç: Bu çalışmanın amacı, stabil intertrokanterik femur kırıklarının (SIFF) tedavisinde proksimal femur çivisi (PFN) ve dinamik kalça vidasının (DHS) maliyet-etkililik, klinik ve radyolojik sonuçlarını karşılaştırmaktı.

Gereç ve Yöntemler: SIFF nedeniyle cerrahi tedavi uygulanan hastalar geriye dönük olarak belirlendi ve tedavi şekline göre iki gruba ayrıldı: Grup 1, 57 hasta (36 kadın, 21 erkek; ortalama yaş $=74,5 \pm 9,9$ yıl) PFN ile tedavi edilen ve Grup 2, DHS ile tedavi edilen 65 hasta (34 kadın, 31 erkek; 72 $\pm 10,2$ yıl). Birincil sonuç ölçütleri; tahmini kan kaybı (EBL), toplam ameliyat süresi (TOT), hastanede kalış süresi (DHS), ameliyat sonrası komplikasyon oranı, ölüm oranı ve tedavi maliyeti olarak yapıldı. Radyografik değerlendirme, ön-arka/yan uç-apeks mesafesini (TAD) ve uzuv uzunluk uyumsuzluğu miktarını (LLD) karşılaştırıldı.

Bulgular: Iki tedavi grubu arasında demografik özelliklerde anlamlı bir farklılık gözlenmedi $(p>0,05)$. Ortalama takip süresi grup $1^{\prime}$ de $44,2 \pm 31$ ay ve grup 2 'de $53,7 \pm 38$ ay idi $(p=0,077)$. Ortalama TOT ve EBL, grup PFN'de grup DHS'ye göre anlamlı olarak daha kısaydı ( $p<0,001$ ve $p=0,03$ ). Ortalama hastanede kalış süresi, postoperatif komplikasyon oranı, mortalite oranı ve tedavi mali-

Corresponding author/iletişim kurulacak yazar: dr.serkanbayram89@gmail.com

Submitted/Başvuru: 07.07.2021 • Revision Requested/Revizyon Talebi: 31.07.2021 •

Last Revision Received/Son Revizyon: 04.08.2021 • Accepted/Kabul: 06.08.2021 • Published Online/Online Yayın: 24.09 .2021 
EBL were significantly shorter in group PFN than in group DHS $(p<0.001$ and $p=0.03)$. No significant difference was observed in the mean duration of hospital stay, rate of postoperative complication, rate of mortality, and treatment cost between the two treatment groups $(p>0.05)$. The post-operative complication rate was $9.5 \%$ in group PFN and $8.3 \%$ in group DHS, with no significant difference $(p=0.83)$. There were significant differences in neither TAD nor LLD between the two treatment groups $(p=0.69$ and $p=0.87$, respectively).

Conclusion: The two treatment modalities seem to have similar effect to maintain stability for patients with stable IFFs. However, less EBL and shorter operation time can be expected from PFN compared to DHS in such patients.

Keywords: Intertrochanteric fracture, dynamic hip screw, proximal femoral nailing, cost-effectivity yeti açısından iki grup arasında anlamlı fark gözlenmedi ( $p>0.05)$. Ameliyat sonrası komplikasyon oranı grup PFN'de \%9,5 ve grup $\mathrm{DHS}^{\prime}$ de $\% 8,3$ idi ve anlamlı bir fark yoktu $(p=0,83)$. I ki tedavi grubu arasında ne TAD ne de LLD'de anlamlı farklılıklar yoktu (sırasıyla $p=0,69$ ve $p=0,87$ ).

Sonuç: Iki tedavi modalitesi, stabil IFF'leri olan hastalarda stabiliteyi sürdürmek için benzer etkiye sahip görünmektedir. Ancak bu tür hastalarda DHS'ye kıyasla PFN'den daha az EBL ve daha kısa operasyon süresi beklenebilir.

Anahtar Kelimeler: Intertrokanterik kırık, dinamik kalça vidası, proksimal femoral çivileme, maliyet etkinliği

\section{INTRODUCTION}

Over the past decades, hip fractures have emerged as a major health problem worldwide confronted by orthopedic surgeons as a consequence of the enhanced longevity of the population and increased incidence of osteoporosis (1). Intertrochanteric hip fractures account for nearly half the hip fractures in elderly patients and lead to obviously diminished life expectancy as well as dramatic impairment in social, economic, and health circumstances (2).

Over the past 30 years, the dynamic hip screw (DHS) has become the implant of choice for the effective treatment of stable intertrochanteric femoral fractures (IFFs) (Arbeitsgemeinschaft für Osteosynthesefragen/Orthopaedic Trauma Association (AO/OTA) 31-A1.1-A1.2), with favorable clinical and radiographic outcomes $(3,4)$. Nonetheless, proximal femoral intramedullary nails (PFNs) have been more widely used for such fractures in recent years, despite the lack of strong evidence to support their superiority over the DHS $(3,4)$.

Current literature illustrates the pros and cons of each treatment modality (1-4). However, to the best of our knowledge, evidences from the existing literature to determine the more advantageous implant to be used in the treatment for stable IFFs are controversial.

Therefore, the primary aim of this study was to compare the efficacy of DHS versus PFN for the management of stable IFFs based on the several clinical and radiographic outcome measures.

\section{MATERIALS AND METHODS}

\section{Data collection and setting of the study}

This retrospective comparative study was conducted on patients who underwent surgical treatment with either PFN or DHS for the treatment of IFFs between 2005 and 2013 at the department of Orthopedics and Traumatolo- gy in a single tertiary referral center. Inclusion criteria for the study were (4):

1. a diagnosis of unilateral stable IFF (AO/OTA 31A1),

2. treated with either DHS or PFN

3. an age above 50 years old

4. a good cognitive function

5. adequate medical and radiographic records.

Exclusion criteria were:

1. a diagnosis of a pathological fracture

2. history of malignancy-metabolic disease or che mo-/radiotherapy

3. history of polytrauma

4. a fracture secondary to high energy trauma (mo tor vehicle accident, fall from a distant height gun-shot injury)

5. bilateral fractures

6. presented with an ASA score IV or higher.

7. Based on the above eligibility criteria, 66 patients were excluded from the study.

\section{Participants}

After obtaining institutional review board approval (Date: 04.04.2021, No: 117), a total of 188 patients were assessed retrospectively according to the above eligibility criteria. After excluding 66 patients, the remaining 122 patients meeting the eligibility criteria were enrolled in the study (Figure 1). All the patients include in the study were then divided into two groups according to the implemented treatment modality: Group 1 (PFN) including 57 patients treated with PFN and group 2 (DHS) including 65 patients treated with DHS.

\section{Surgical technique}

All patients were hospitalized from the emergency room and were managed with low molecular weight heparin and thromboembolic-deterrent stockings for prophylaxis of deep venous thrombosis. Then, all stable IFFs were treated operatively at the earliest opportunity, by three 


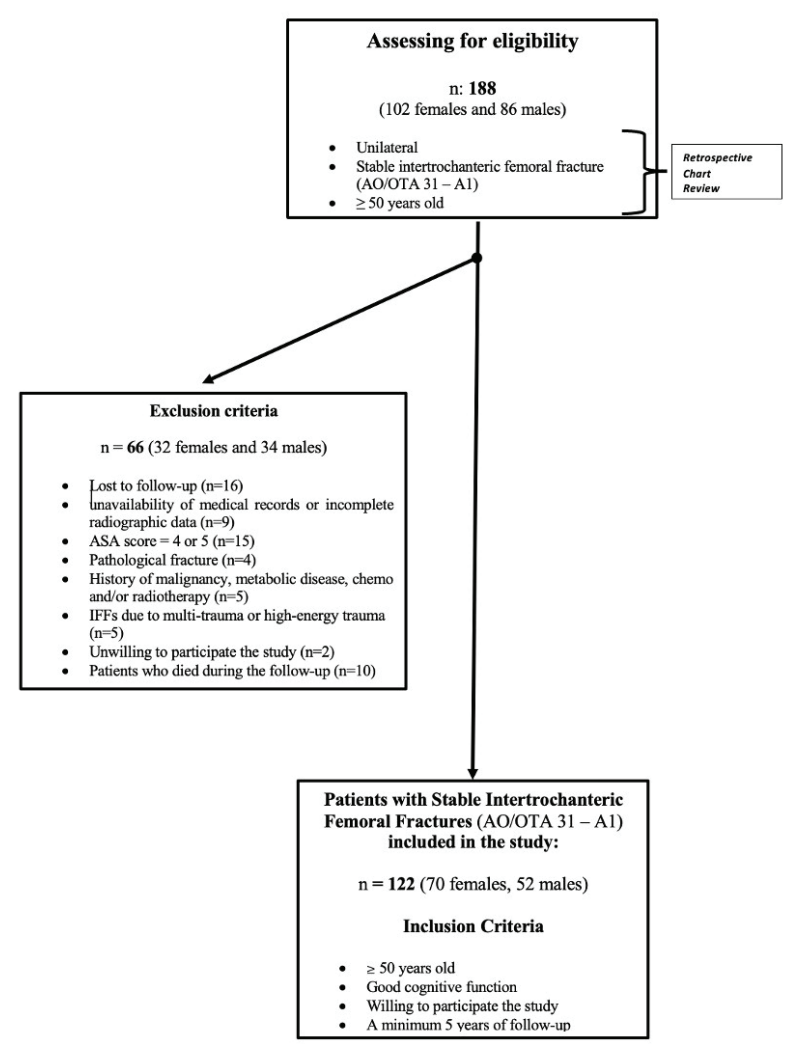

Figure 1: Flowchart of the study population, together with the inclusion and exclusion criteria

experienced orthopedic trauma surgeons either executing the operation or in attendance.

The type of implant used was decided based on the surgeon's preference and experience. After patients were placed supine on an orthopedic traction table, fractures were reduced by traction and internal rotation with the injured limb in a slightly adducted or neutral position to allow an introduction to the greater trochanter. The reduction was then checked, and implants were applied under image intensifier.

In group DHS, a DHS with a four-hole and 135 degrees plate (Dynamic Hip System screw/blade; Synthes GmbH, Basel, Switzerland) was inserted without any additional anti-rotational screw. In group PFN, proximal femoral nail anti-rotation (PFNA) (Synthes GmbH, Oberdorf, Switzerland) was performed (Figure 2, 3). In all patients, efforts had been paid to ideally place the tip of the screw within the subchondral bone of the femoral head with a combined tip-apex distance measuring less than $25 \mathrm{~mm}$ on anteroposterior and lateral radiographs.

\section{Postoperative management and follow-up period}

Patients were mobilized with partial weight bearing as tolerated at the second day after surgery, which was increased gradually according to the stability of the fracture and prefer-

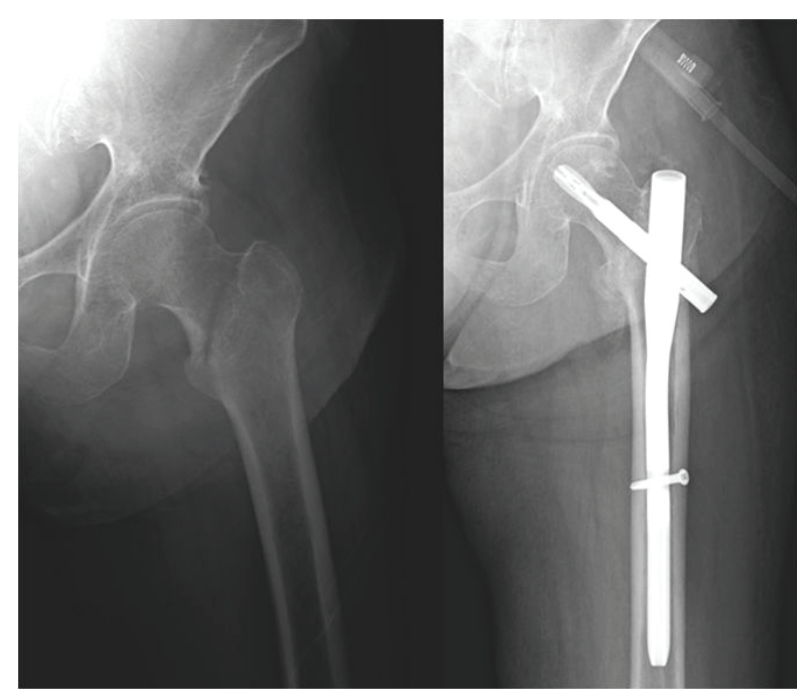

Figure 2: Pre- and post-operative AP X-ray of a 78-yearold patient with stable intertrochanteric femur fracture that was treated with PFN

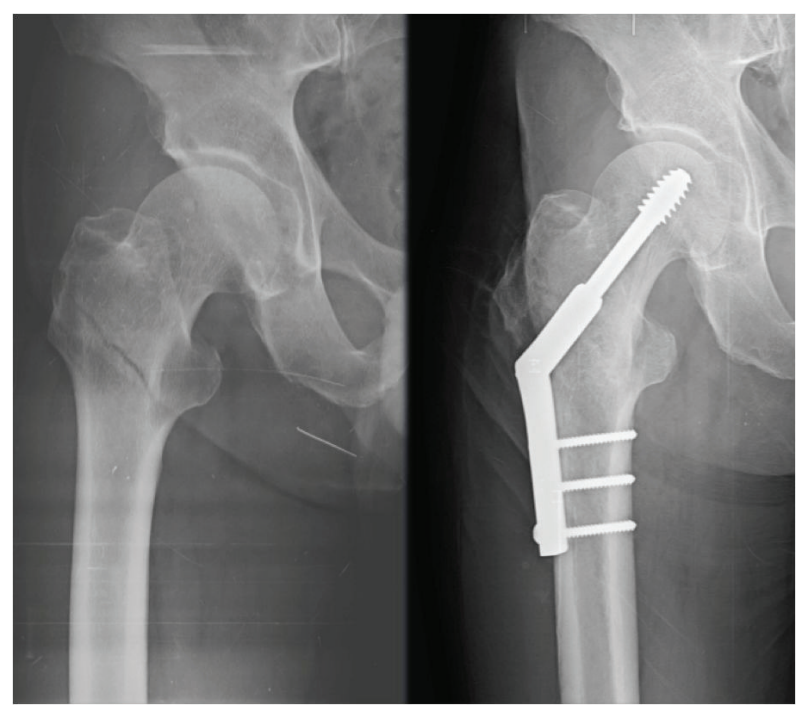

Figure 3: Pre- and post-operative AP X-ray of an 81-yearold patient with stable intertrochanteric femur fracture that was treated with DHS

ence of the operating surgeon in PFN group. Patients were mobilized at the second day after surgery with no weight bearing until the bony union was confirmed radiographically in DHS group. All patients were recalled for regular follow-up examinations at the second $, 6^{\text {th }}, 12^{\text {th }}, 24^{\text {th }}$ week and once a year. During each follow-up visit, patients' functional status was assessed. To prevent any bias while comparing the total costs of two groups, implant costs were excluded.

\section{Outcome measures}

\section{- Clinical assessment}

The invasiveness of each operation was assessed based on the data including total operating time (TOT), estimat- 
ed blood loss (EBL), duration of hospital stays (DHS), rate of postoperative complications, rate of mortality, and total hospital cost. All the relevant data were documented from our institution medical records including plain radiography, operative notes, information on demographic characteristics, discharge reports, and progress notes. EBL was calculated using the Mercuriali's formula (5). To prevent any bias while comparing the total costs of two groups, implant costs were excluded.

\section{- Radiographic assessment}

The position of the implants was examined measuring the tip-apex distance (TAD) on latest postoperative follow-up radiographs of the patients including anteroposterior (AP) pelvis and lateral hip views as per the method of Baumgaertner et al. (6). Also, femoral neck-shaft angle was measured on the AP hip radiographs.

\section{Statistical analysis}

For the statistical analysis, SPSS software (Version 22.0; SPSS Inc, Chicago, IL, USA) was used. Normality of distribution was tested using the Shapiro-Wilk test. Student's t-test was used to compare quantitative data, normally distributed variables of descriptive statistics (mean, standard deviation, median, frequency, rate, minimum and maximum). Pearson chi-square test, Fisher-Freeman-Halton test, and Fisher's exact test were used to compare qualitative variables. A p-value less than 0.05 was considered as statistically significant.

\section{RESULTS}

\section{Baseline characteristics}

No significant differences were observed in demographic characteristics between the two treatment groups $(p>0.05)$. Group PFN consisted of 36 females and 21 males, and there were 34 females and 31 males in group DHS ( $p=0.227)$. The mean age was $74.7 \pm 10$ years in group PFN and $72 \pm 9.9$ years in group DHS $(p=0.166)$. The mean follow-up was $44.2 \pm 31$ months in group PFN and $53.7 \pm 38$ months in group DHS $(p=0.077)$ (Table 1).

\section{Clinical outcomes}

The mean TOT was significantly shorter in group PFN ( $90.3 \pm 19$ minutes) than in group DHS (107.1 \pm 26 minutes) $(p<0.001)$. The mean EBL was significantly less in group PFN (361 $\pm 79 \mathrm{ml})$ than in group DHS $(535 \pm 90 \mathrm{ml})(p=0.03)$. No significant difference was observed in the mean duration of hospital stay between the two treatment groups (6.62 \pm 1.8 days for group PFN vs $7.5 \pm 3$ days for group DHS [ $p=0.165]$ (Table 2).

The post-operative complication rate was $9.5 \%$ in group PFN and $8.3 \%$ in group DHS, with no significant difference $(p=0.83$ ). Two patients developed pulmonary embolus, and three patients superficial wound side problems in group PFN. Two patients developed pulmonary embolism and three patient superficial wound side problem in group DHS. The mortality rate was $73.6 \%$ (42 patients) in group PFN and $67.6 \%$ (44 patients) $(p=0.469)$.

The mean total hospital cost $1546.86 \pm 444.2$ USD in group PFN and $1508.59 \pm 444.21$ USD in group DHS. No significant difference was observed in terms of hospital costs between both groups $(p=0.828)$.

\section{Radiographic outcomes}

The mean femoral-neck-shaft angle was $132.5^{\circ}$ (range= $121^{\circ}-139^{\circ}$ ) in group PFN and $133.6^{\circ}$ (range $=127^{\circ}-138^{\circ}$ ) in group DHS $(p=0.83)$. The mean AP/lateral tip apex distance was, respectively, $10.3 \mathrm{~mm}$ (range $=4.2-13.1$ ) and 9.9 $\mathrm{mm}$ (range $=6.1-12.7$ ) in group PFN as well as $11.8 \mathrm{~mm}$ (range=8.3-15.2) and $10.4 \mathrm{~mm}$ (range=6.5-14.2) in group DHS. There were significant differences in neither AP nor lateral tip apex distances between the two treatment groups ( $p=0.69$ and $p=0.87$, respectively). The mean postoperative LLD was $0.78 \mathrm{~mm}$ (range $=0-1.4$ ) in group PFN and $0.8 \mathrm{~mm}$ (range $=0-1.6$ ) in group DHS, with no significant difference $(p=0.74)$ (Table 2).

\section{DISCUSSION}

Over the last two decades, there has been a great controversy regarding the optimum treatment of stable IFFs PFN and DHS have been compared each other with respect to the clinical outcomes, biomechanical strength, rates of failure, rates of implant-related (blade cut- out, peri-prosthetic fracture) and patient-related (morbidity-mortality) complications, as well as the technical difficulties $(7,8)$. Current literature illustrates the pros and cons of each treatment modality. However, to the best of our knowledge, evidences from the existing literature to determine the more advantageous implant to be used in the treatment for stable IFFs are controversial. Data obtained from the current study have found no significant differences in clinical and radiological outcomes except EBL and TOT which were higher in group DHS.

According to a large Cochrane review, DHS was regarded as the gold standard for the treatment of stable IFFs because of the lower rates of complications and reoperations compared to PFN (8). These results were also supported by many other studies $(8-10,11)$. In the present study, no statistically significant difference was found with regard to complication rates between the two groups $(p=0.83)$.

Many studies underlined that there was no significant difference between PFN and DHS with regard to bleeding which was another important intra- and post-operative concern $(7,10)$. EBL was found higher in group DHS compared to PFN detected with a low statistical significance $(p=0.048)$. We believe that this small difference may have possibly occurred because of the technical principles of conventional DHS application. As shown in the literature, performing the 
Table 1: Demographic data of both groups

\begin{tabular}{|c|c|c|c|c|c|}
\hline & \multicolumn{2}{|c|}{ PFN group } & \multicolumn{2}{|c|}{ DHS group } & \multirow{2}{*}{$P$ value } \\
\hline & Mean \pm SD & Min-Max & Mean \pm SD & Min-Max & \\
\hline Age (years) & $74.7 \pm 10$ & $50-94$ & $72 \pm 9.9$ & $53-97$ & 0.166 \\
\hline Gender (F/M) & \multicolumn{2}{|c|}{$36 / 21$} & \multicolumn{2}{|c|}{$34 / 31$} & 0.227 \\
\hline Follow-up (months) & $44.2 \pm 31$ & $12-140$ & $53.7 \pm 38$ & $12-144$ & 0.077 \\
\hline Side (R/L) & \multicolumn{2}{|c|}{$29 / 28$} & \multicolumn{2}{|c|}{$36 / 29$} & 0.619 \\
\hline
\end{tabular}

SD: Standard Deviation; Min: Minimum; Max: Maximum; F: Female; M: Male; R: Right; L: Left

Table 2: Summary of mean clinical parameters

\begin{tabular}{lccc}
\hline & $\begin{array}{c}\text { Group 1 (PFN) } \\
\text { Mean } \pm \text { SD }\end{array}$ & $\begin{array}{c}\text { Group 2 (DHS) } \\
\text { Mean } \pm \text { SD }\end{array}$ & P value \\
\hline Duration of surgery (min) & $90.3 \pm 19$ & $107.1 \pm 26$ & $<0.001$ \\
Estimated blood loss (ml) & $361 \pm 79$ & $535 \pm 90$ & 0.03 \\
Duration of hospital stay, (day) & $6.62 \pm 1.8$ & $7.5 \pm 3$ & 0.165 \\
Post-operative complications, (\%) & 9.5 & 8.3 & 0.83 \\
Mortality, (\%) & 73.6 & 67.6 & 0.469 \\
Time to unassisted mobilization & $32.17 \pm 6.39$ & $32.78 \pm 5.39$ & 0.93 \\
Mean total hospital costs when & $1546.86 \pm 444.2$ & $1508.59 \pm 444.21$ & 0.828 \\
the implant costs are excluded & & & \\
Femoralneck-shaft angle, $\left({ }^{\circ}\right)$ & $132.5 \pm 4.2$ & $133.6 \pm 3.1$ & 0.83 \\
AP tip apex distance, $(\mathrm{mm})$ & $10.3 \pm 2.7$ & $11.8 \pm 3.2$ & 0.69 \\
Lateral tip apex distance, $(\mathrm{mm})$ & $9.9 \pm 1.9$ & $10.4 \pm 3.7$ & 0.87 \\
\hline
\end{tabular}

SD: Standard deviation; min: minute; ml: mililiter; mm: milimeter; USD: United Stade Dollars

DHS minimally invasively may reduce the amount of total average blood loss in such patients $(11,12)$.

In the recent literature, duration of operations which directly influenced patients' prognosis and surgeon's performance was found to be similar between the two treatment modalities in concordance with the results of the present study $(13,14)$. This was probably due to experienced surgical team which could perform both surgeries with similar precision in terms of the surgical technique. The recent literature failed to show any significant difference between the two groups with regard to the duration of hospital stay, while some studies detected that the PFN group had a significantly longer hospital stay (7, $8,15)$. The results of our study have shown that patients receiving DHS were hospitalized for a longer duration as compared to those receiving PFN, while no statistical significance was detected.

Without the exclusion of the implant costs, total hospital costs of PFN were previously reported more expensive than DHS $(8,16-20)$. We considered that the inclusion of implant cost in the comparison may have causes a high susceptibility to bias because of higher implant costs of
PFN as compared to DHS. Accordingly, to prevent such a bias, we excluded the costs of the implants and found similar total hospital costs regardless of the implant type. Also, we believe that this was an expected result because of the demographical comparability of the two groups.

Memon et al. reported a study which investigated the fracture union and collapse, femur neck shortening, implant position and failure or collapse (cut out risk) (21). In that study, they found that PFN group demonstrated no implant cut out and less mean limb length shortening. Ricci et al. reported a study which investigate the secondary collapse is related to fixation method in 2-part intertrochanteric femur fractures in patients treated with PFN versus DHS (22). In that study, these fractures are not necessarily stable when treated with DHS and dual screw PFN seems to be most effective to maintain stability for patients with this fracture pattern.

Finally, some limitations and strengths of the current study should be taken into account. The main limitation was the retrospective nature of the study with a relatively low number of cases. Another limitation is that this study did not include the Oxford, Harris, Modified Harris, 
HOOS, WOMAC scores to perform a functional evaluation. Bone quality of patients were not investigated which effect the bone union and radiological parameters. Lastly, other factors affecting mortality, such as chronic steroid use, sarcopenia, and cancer were not investigated. The main strength of this study was to provide a solution for the controversy in the literature in terms of the ideal management strategy of sIFFs by underlining that DHS was a more cost-effective method of treatment. However, it should also be highlighted that unstable IFFs were diagnosed more frequently in older patients as compared to stable IFFs, while intramedullary nailing was considered as the gold standard for the management of unstable IFFs for its biomechanical properties (17-20). To confer a better understanding about the optimal treatment of stable IFFs, large prospective randomized studies are needed.

The present study concluded that, for stable IFFs, fixation with dynamic hip screw versus proximal femoral nail had no significant difference with regard to duration of hospital stays, rates of post-operative complications and mortality and time until unassisted mobilization, while both groups were noted to have similar radiographic results. Within 40 years following surgery, the two treatment modalities have similar effective to maintain stability for patients with this fracture pattern and complication rate (19-22). However, PFN have lower duration of operation and blood loss than DHS.

Informed Consent: Written consent was obtained from the participants.

Ethics Committee Approval: This study was approved by the Ethical Committee of the Istanbul University Istanbul Faculty of Medicine (Date: 04.04.2021, No: 117).

Peer Review: Externally peer-reviewed.

Author Contributions: Conception/Design of Study- T.P., S.B., M.C., M.D.; Data Acquisition- S.B., M.C., E.K.; Data Analysis/ Interpretation- T.A., A.S., S.B., M.D.; Drafting Manuscript- T.P., S.B., M.D., T.A.; Critical Revision of Manuscript- Ö.Y., T.A., A.S.; Final Approval and Accountability- T.P., S.B., M.D., M.C., E.K., A.S., T.A., Ö.Y.

Conflict of Interest: Authors declared no conflict of interest.

Financial Disclosure: Authors declared no financial support.

Bilgilendirilmiş Onam: Katılımcılardan bilgilendirilmiş onam alınmıştır.

Etik Komite Onayı: Bu çalışma için etik komite onayı İstanbul Üniversitesi, İstanbul Tıp Fakültesi Etik Kurulu'ndan alınmıştır (Tarih: 04.04.2021, No: 117).

\section{Hakem Değerlendirmesi: Dış bağımsız.}

Yazar Katkıları: Çalışma Konsepti/Tasarım- T.P., S.B., M.C., M.D.; Veri Toplama- S.B., M.C., E.K.; Veri Analizi/Yorumlama- T.A., A.S., S.B., M.D.; Yazı Taslağı- T.P., S.B., M.D., T.A.; İçeriğin Eleştirel Incelemesi- Ö.Y., T.A., A.S.; Son Onay ve Sorumluluk- T.P., S.B., M.D., M.C., E.K., A.S., T.A., Ö.Y.

Çıkar Çatışması: Yazarlar çıkar çatışması beyan etmemişlerdir.

Finansal Destek: Yazarlar finansal destek beyan etmemişlerdir.

\section{REFERENCES}

1. Veronese N, Maggi S. Epidemiology and social costs of hip fracture. Injury 2018;49(8):1458-60. [CrossRef]

2. Mundi S, Pindiprolu B, Simunovic N, Bhandari M. Similar mortality rates in hip fracture patients over the past 31 years: A systematic review of RCTs. Acta Orthop 2014;85(1):54-9. [CrossRef]

3. Marsh JL, Slongo TF, Agel J, Broderick JS, Creevey W, DeCoster TA, et al. Fracture and dislocation classification compendium - 2007: Orthopaedic Trauma Association classification, database and outcomes committee. J Orthop Trauma 2007;21(10 Suppl):S1-133. [CrossRef]

4. Barton TM, Gleeson R, Topliss C, Greenwood R, Harries WJ, Chesser TJ. A comparison of the long gamma nail with the sliding hip screw for the treatment of AO/OTA 31-A2 fractures of the proximal part of the femur: a prospective randomized trial. J Bone Joint Surg Am 2010;92(4):792-8. [CrossRef]

5. Irisson E, Hémon Y, Pauly V, Parratte $S$, Argenson JN, Kerbaul F. Tranexamic acid reduces blood loss and financial cost in primary total hip and knee replacement surgery. Orthop Traumatol Surg Res 2012;98(5):477-83. [CrossRef]

6. Baumgaertner MR CS, Lindskog DM, Keggi JM. The value of the tip apex distance in predicting failure of fixation of peritrochanteric fractures of the hip. J Bone Joint Surg (Am) 1995;77:1058-64. [CrossRef]

7. Matre K, Vinje T, Havelin LI, Gjertsen JE, Furnes O, Espehaug $B$, et al. TRIGEN INTERTAN intramedullary nail versus sliding hip screw: a prospective, randomized multicenter study on pain, function, and complications in 684 patients with an intertrochanteric or subtrochanteric fracture and one year of follow-up. J Bone Joint Surg Am 2013;95(3):200-8. [CrossRef]

8. Parker MJ, Handoll HH. Gamma and other cephalocondylic intramedullary nails versus extramedullary implants for extracapsular hip fractures in adults. Cochrane Database Syst Rev 2008;(3):CD000093. [CrossRef]

9. Aune AK, Ekeland A, Odegaard B, Grogaard B, Alho A. Gamma nail vs compression screw for trochanteric femoral fractures. 15 reoperations in a prospective, randomized study of 378 patients. Acta orthopaedica Scandinavica 1994;65(2):127-30. [CrossRef]

10. Hardy DC, Descamps PY, Krallis P, Fabeck L, Smets P, Bertens $C L$, et al. Use of an intramedullary hip-screw compared with a compression hip-screw with a plate for intertrochanteric femoral fractures. A prospective, randomized study of one hundred patients. J Bone Joint Surg Am 1998;80(5):618-30. [CrossRef] 
11. Herrera A, Domingo LJ, Calvo A, Martínez A, Cuenca J. A comparative study of trochanteric fractures treated with the Gamma nail or the proximal femoral nail. Int Orthop 2002;26(6):365-9. [CrossRef]

12. Abreu ELd, Sena CB, Rodrigues Filho SAS. Effectiveness of treatment of transtrochanteric fractures with Dynamic Hip Screws using minimally invasive access. Rev Bras Ortop 2016;51(2):138-42. [CrossRef]

13. Mahmood A, Kalra M, Patralekh M. Comparison between conventional and minimally invasive dynamic hip screws for fixation of intertrochanteric fractures of the femur. ISRN Orthop 2013;2013:484289 [CrossRef]

14. Saudan M, Lübbeke A, Sadowski C, Riand N, Stern R, Hoffmeyer P. Pertrochanteric fractures: is there an advantage to an intramedullary nail?: a randomized, prospective study of 206 patients comparing the dynamic hip screw and proximal femoral nail. J Orthop Trauma 2002;16(6):386-93. [CrossRef]

15. Aros B, Tosteson AN, Gottlieb DJ, Koval KJ. Is a sliding hip screw or im nail the preferred implant for intertrochanteric fracture fixation? Clin Orthop Relat Res 2008;466(11):282732. [CrossRef]

16. Aktselis I, Kokoroghiannis C, Fragkomichalos E, Koundis G, Deligeorgis A, et al. Prospective randomised controlled trial of an intramedullary nail versus a sliding hip screw for intertrochanteric fractures of the femur. Int Orthop 2014;38(1):155-61. [CrossRef]
17. Kumar R, Singh R, Singh B. Comparative prospective study of proximal femoral nail and dynamic hip screw in treatment of intertrochanteric fracture femur. J Clin Orthop Trauma. 2012;3(1):28-36. [CrossRef]

18. Taeger G, Schmid C, Zettl R, Schweiberer L, Nast-Kolb D. Stable and unstable pertrochanteric femoral fractures. Differentiated indications for the dynamic hip screw. Unfallchirurg 2000;103(9):741-8. [CrossRef]

19. Lavini F, Renzi-Brivio L, Aulisa R, Cherubino F, Di Seglio $\mathrm{PL}$, Galante N, et al. The treatment of stable and unstable proximal femoral fractures with a new trochanteric nail: results of a multicentre study with the Veronail. Strategies Trauma Limb Reconstr 2008;3(1):15-22. [CrossRef]

20. ZZhang S, Zhang K, Jia Y, Yu B, Feng W. InterTan nail versus Proximal Femoral Nail Antirotation-Asia in the treatment of unstable trochanteric fractures. Orthopedics 2013;36(3):182e292. [CrossRef]

21. Memon K, Siddiqui AM, Khan ZA, Zahoor A. Dynamic hip screw fixation vs. proximal femur nail for unstable pertrochanteric fractures: a comparative analysis of outcomes and complications. J Ayub Med Coll Abbottabad. 2021;33(1):34-38.

22. Ricci MJ, McAndrew CM, Miller AN, Kamath G, Ricci WM. Are two-part intertrochanteric femur fractures stable and does stability depend on fixation method? J Orthop Trauma 2019;33(9):428-431. [CrossRef] 